\title{
The Post-Effect of IFRS Adoption on Financial Position: An Empirical Study of Indian SMSEs
}

\author{
Dr. Faran Ahmad Qadri \\ Department of Accounting, College of Business, King Abdulaziz University, Rabigh - 21911, Saudi Arabia
}

\begin{abstract}
The progressive country like India, now days Small and Medium Scale Enterprises (SMSEs) are contributing a remarkable share to country's economy. SMSEs now considered as backing up to different economic prospective such as unemployment, GDP, FDI, etc. The globalization era witness of significant growth in integration of economy and capital market of countries and every organization of these countries want to expansion internationally and to raise capital for expansion organizations are not limiting themselves only to domestic capital market and to lead in the market, there is obliged fairness in accounting angle to check, study and examine the genuine financial position of the organization itself and outsiders like investor, authorized body and so on. On this regards International Financial Reporting Standards (IFRS) playing significant part to make standardized financial statements which can acceptable both national and international. In view of objective of this study a comparative approach adopted. Date collected from annual reports of SMSEs which are enlisted in BSE for the period of 4 year. The financial ratios like current ratio, returns on asset and earnings per share ratio taken as measure of profitability, liquidity and market of company for this study.
\end{abstract}

Keywords: IFRS, SMSEs, Financial position, financial reporting.

DOI: $10.7176 /$ RJFA/10-24-08

Publication date: December $31^{\text {st }} 2019$

\section{Introduction}

We are now living in global economy at the same time our business setups are operating internationally. Globalization brings change in trade practice and inbound and outbound investment becomes the part of current business's life. In current era distances are getting less importance and the world gazing as a little global town. As the globe is now being considered as global town, good financial reporting system will be a part of priority category of prerequisite list to operate a business successfully. It's also no wonder that pace of voluntarily adoption of globally recognized accounting standard is increased. In view of this, it is become essential to set a universally standards cross different countries and to have uniformity in policy framework which can well defined and structured the practice of accounting. Therefore IFRS have been considered as language for global business which make possible for stakeholders to understand and compare global business affairs. IFRS now act as yard stick to measure the performance of business unit irrespective of its size. The adoption of IFRS not only useful for organization itself but also helps to investors to know the actual financial position of business units operated in worldwide.

The implementation of IFRS among various countries is seems as a big issue due to uniformity, comparability and reliability. Apart from presenting the true position of an organization, it also informing about performance, variation in capital composition and cash flows of the business (Adetula, 2016). These facts are useful to all interested parties for taking economical decisions. The quality of financial report is indispensable for the need of users who requiring for investment and other financial decision. However, the adoption of IFRS deals with lots of problems such as lack of transparency and poor governance resulted of half complete records and narrow scope of administration in the SMSEs.

However, there is limited number of literatures on financial ratios and due adoption of IFRS effect on these financial ratios of SMSEs in India are available. In this study examine the comparison between financial ratios of SMSEs prepared under GAAP and IFRS. The aim of this study is to examine is there any significant differences are exists between financial ratios of Indian small medium scale enterprises before adoption of IFRS and after adoption IFRS. For this purpose this study current ratio to check liquidity, operating profit ratio to check profitability, and EPS to check performance growth of SMSEs.

\section{Small and Medium Scale Enterprises (SMSEs)}

According to Section-7 of MSMED Act, 2006, "In India, the manufacturing enterprises grouped into SMSEs which enterprises are having investment in plant and machinery or equipments is ranging from Rs. 25Lakhs (\$ 0.04 million) to Rs. 10 crores ( $\$ 1.6$ million) where as investment ranging from Rs. 10 Lakhs (\$ 0.02 million) to Rs. 5 Crores ( $\$ 0.8$ million) will be grouped into Small medium scale service sector enterprise.” This Act classified enterprises of India on the basis of size of investment and nature of business activities of an enterprise. According to this Act "Indian enterprises are mainly classified into two categories named as manufacturing enterprises \& service enterprises". For each category, a separate definition is given to explain 
about constitutes for a micro enterprise or a small enterprise or a medium enterprise. The investment limit on plant and machinery in case of manufacturing and on equipment in case of service sector, category and nature of undertaking as notifies on 20/09/2016 are summed up as follows

Table-1: Classification of Indian SMSEs

\begin{tabular}{|c|c|c|c|}
\hline $\begin{array}{l}\text { Type of } \\
\text { Sectors }\end{array}$ & Nature of Undertaking & $\begin{array}{l}\text { Category of } \\
\text { Enterprise }\end{array}$ & $\begin{array}{c}\text { Amount of investment in Plant \& } \\
\text { Machinery/Equipment }\end{array}$ \\
\hline \multirow{3}{*}{ Manufacturing } & \multirow{3}{*}{$\begin{array}{l}\text { "Engaged in the manufacture } \\
\text { or production of goods } \\
\text { pertaining to any industry } \\
\text { specified in the first schedule } \\
\text { to the Industries } \\
\text { Development and Regulation } \\
\text { Act, } 1951 \text { or employing plant } \\
\text { and machinery in the process } \\
\text { of value addition to the final } \\
\text { product having a distinct } \\
\text { name or character or use." }\end{array}$} & Micro & $\begin{array}{l}\text { Investment does not exceed Rupees } 25 \\
\text { lakhs }\end{array}$ \\
\hline & & Small & $\begin{array}{l}\text { Investment in between Ruppes } 25 \text { Lakhs } \\
\text { to Rupees } 5 \text { Crores }\end{array}$ \\
\hline & & Medium & $\begin{array}{l}\text { Investment in between Rupees } 5 \text { Crores to } \\
\text { Rupees } 10 \text { Crores }\end{array}$ \\
\hline \multirow{3}{*}{ Service } & \multirow{3}{*}{$\begin{array}{l}\text { "Engaged in providing or } \\
\text { rendering of services." }\end{array}$} & Micro & $\begin{array}{l}\text { Investment does not exceed Rupees } 10 \\
\text { lakhs }\end{array}$ \\
\hline & & Small & $\begin{array}{l}\text { Investment in between Rupees } 10 \text { Lakhs } \\
\text { to Rupees } 2 \text { Crores }\end{array}$ \\
\hline & & Medium & $\begin{array}{l}\text { Investment in Between Rupees } 2 \text { Crores to } \\
\text { Rupees } 5 \text { Crores }\end{array}$ \\
\hline
\end{tabular}

According to definition, SMSEs can start in any form of business such as sole-proprietorship, partnerships, company, associations of persons, cooperatives and HUFs, etc. Further, this definition is not having restriction neither on number of employee nor on consumption of electricity using firms as previously practiced in India and still practiced in some countries.

However, IASB (2016) defines

"SMEs as entities that are not in the process of issuing debt or equity securities for trading in a public market; that do not hold assets in fiduciary capacity for a broad group of outsiders as one of their primary businesses; that have annual turnover of not more than N500 million (approximately US\$3 million); that have total assets value of not more than N200 million (approximately US\$1 million); that have no foreign Board members; that have no members that are a government or a government corporation or agency or its nominee; and whose directors together hold not less than 51 per cent of its equity share capital."

\section{Theoretical Background}

The concept of "Capital Need Theory" adopted for this research study. This theory state that, "companies that have some growth opportunities in the capital market seek external financing from the capital market". To achieve this enterprises can issue more number of share or can borrow from external stakeholders (Core, 2001). Therefore, such type of external financing requires kind of competition among companies in order to obtain capital as cost-effectively as possible. Capital need theory explains reason to prepare financial statement and disclosures of financial statement according to IFRS and GAAP together which is not mandatory previously. Therefore Capital needs theory taken into consider for this study is justified because now number of SMSEs for reaping expanding opportunities started to enlist in various stock exchanges to arrange fund from the world capital markets. In order to fulfill this objective, SMSEs need to disclose more but genuine information to investors to aware them about company's financial performance and financial position.

\section{LITERATURE REVIEW}

Researcher in his study which titled "A Perception Based Analysis of the Mandatory Adoption of IFRS in Nigeria" shown there is significant difference in stakeholder's perception towards the advisability of making mandatory for IFRS adoption. (Isenmila and Adeyemo, 2013)

"Adoption of IFRS and Financial Statements Effects The Perceived Implications on FDI and Nigeria Economy". (Kenneth, 2012) Finding of this study reveals that IFRS has been adopted in country but only few number of corporate takes initiation for voluntary implementation of IFRS with deadline for the others to comply. This study also perceived that implementation of IFRS will elevate inflows of FDI and ultimately growth of economy of country. (Kenneth, 2012)

A study titled "Mandatory IFRS Reporting around the World: Early Evidence on the Economic Consequences" in which 3,100 corporate from 26 countries undertaken. This study noted that the company which adopted IFRS invent with lots of unassailable financial gains in countries with uncompromising rules and 
regulation over financial reporting. (Daske, Hail, Leuz and Verdi, 2007)

This study elaborately discuss about the advantageous and problems of IFRS adoption. In this paper they try to discuss the impact of IFRS by restricting the study into Indian banking industry. In this study, they elaborated number of benefits of IFRS such as possibility to access the global financial market, easily company can listed in cross broader exchange and many more. On other side the adoption of IFRs also brings lots of challenges such as shortage of trained manpower, creating of awareness etc. for the bank. (Thapa, Shankar (2012)

Some research paper also pointed out in their study, that the firm's performances which are adopted IFRS system to preparing financial statement dependent on number of other factors. In this paper they also argued IFRS not having much effect in firm's growth. (Akhidime (2010), Okafor and Killian (2011).

On the basis of existing literatures, it is evident that less number of research studies shows how IFRS practice affect on different economic activities of corporate and other important financial activity by the adoption of IFRS by companies. Some of research article also study on difference of corporate performance during Local GAAP and on limited industry. Basically, adoption of IFRS is viewed as only a commitment for fair and better qualitative disclosure, which may have directly or indirectly impacts on performance of Indian enterprises including SMSEs, which is required to be filling the gap and thus check the impact on financial position after IFRS adoption by SMSEs.

\section{Objective and hypothesis}

The aim of this study is to show the impact on economical performance and financial position of SMSEs having operation in India and started to use IFRS in presentation of financial report. To check the impact of adoption IFRS, the pre and post performance indices of selected SMSEs taken into study. The objectives of this study are as follows:

a) To see changes in liquidity position of Indian SMSEs before and after IFRS adoption.

b) To determine up to what extent IFRS adoption affects growth of Indian SMSEs.

c) To ascertain pre \& post effect of using IFRS standards on the ROA of Indian SMSEs.

d) To determine whether adoption of IFRS affects to EPS of Indian SMSEs.

To consummate objective of this study, the following hypotheses are taken as Null hypotheses:

1. The liquidity position of Indian SMSEs does not significantly affect after IFRS adoption.

2. The performance growth of Indian SMSEs does not significantly affect after IFRS adoption.

3. The return on asset of Indian SMSEs does not significantly affect after adoption of IFRS

4. The earnings per share does not significantly affect after adoption of IFRS.

\section{Methodology}

The methodology, procedures and techniques explores in carrying out the analysis and interpret the data of study are exposited in order to provide obviously unbiased and meaningful result. Data for this study are collected from published annual reports of SMSEs listed on BSE from 2009 to 2012 as pre-adoption and from 2013 to 2016 as post-adoption taken into study. After-the-fact research method is used for this study. It is established to prognosticate and envision the effect of using IFRS standard on financial positions and performance of SMSEs in India. For this study one of non-probability sampling technique i.e. subjective sampling technique was adopted to select 5 SMSEs in India.

Table 2: Definition of variable and measurement

\begin{tabular}{|c|l|l|}
\hline SL. NO. & \multicolumn{1}{|c|}{ Variables } & \multicolumn{1}{c|}{ Measurement } \\
\hline 1 & IFRS & $\begin{array}{l}\text { Comparing measure adopted and compare the results before and after adoption of } \\
\text { IFRS }\end{array}$ \\
\hline 2 & Liquidity & $\begin{array}{l}\text { To check the liquidity position "total current assets divided by total current } \\
\text { liability" taken into study }\end{array}$ \\
\hline 3 & $\begin{array}{l}\text { Growth } \\
\text { performance }\end{array}$ & $\begin{array}{l}\text { To check this variable "current year's dividend performance divided by previous } \\
\text { year performance" taken into account and to drive in percentage the result multiplied } \\
\text { by 100. }\end{array}$ \\
\hline 4 & Return on Assets & $\begin{array}{l}\text { To check this variable "Ratio of Operating profit after interest \& tax and Total } \\
\text { Assets" taken as measure }\end{array}$ \\
\hline 5 & $\begin{array}{l}\text { Earnings per } \\
\text { share }\end{array}$ & $\begin{array}{l}\text { To check this variable "Ratio of Operating profit after interest, tax and preferred } \\
\text { dividend and number of outstanding shares" taken as measure. }\end{array}$ \\
\hline
\end{tabular}




\section{Data Analysis and Results}

The data required for the study was presented on following table no -3

Table - 3

\begin{tabular}{|c|c|r|r|r|r|}
\hline PERIOD & Years & Liquidity & \multicolumn{1}{c|}{ PERG } & \multicolumn{1}{c|}{ ROA } & \multicolumn{1}{c|}{ EPS } \\
\hline \multirow{4}{*}{ Pre-Adoption } & 2009 & 5.63 & 1316.76 & 6.55 & 323.66 \\
\cline { 2 - 6 } & 2010 & 6.27 & 1113.12 & 7.76 & 51.39 \\
\cline { 2 - 6 } & 2011 & 5.82 & 123.15 & 6.42 & 734.58 \\
\cline { 2 - 6 } & 2012 & 6.29 & 26957.6 & 7.9 & 648.74 \\
\cline { 2 - 6 } & Total & 24.01 & 29510.59 & 28.63 & 1758.37 \\
\hline \multirow{4}{*}{ Post-Adoption } & 2013 & 5.96 & 223.23 & 9.66 & 486.31 \\
\cline { 2 - 6 } & 2014 & 6.12 & 385.3 & 8.5 & 1241.82 \\
\cline { 2 - 6 } & 2015 & 5.91 & 421.37 & 5.94 & 705.21 \\
\cline { 2 - 6 } & 2016 & 5.95 & 63.44 & 5.6 & 1002.44 \\
\cline { 2 - 6 } & Total & 23.94 & 1093.34 & 29.7 & 3435.78 \\
\hline
\end{tabular}

\subsection{Hypothesis Testing}

In this study Wilcoxon statistical tool used to test the linearity between the variables through SPSS 20 and the result is presented in tabular form as below:

$\mathrm{H}_{01}$ : There is no significant effect on liquidity position of SMSEs by adoption of IFRS

Table - 4: Effect of IFRS on Liquidity Position of Indian SMSEs

Hypothesis Test Summary

\begin{tabular}{|l|l|l|l|l|}
\hline & \multicolumn{1}{|c|}{ Null Hypothesis } & \multicolumn{1}{|c|}{ Test } & \multicolumn{1}{c|}{ Sig. } & \multicolumn{1}{c|}{ Decision } \\
\hline \multirow{4}{*}{1} & $\begin{array}{l}\text { Related- } \\
\text { The median of differences between } \\
\text { The Liquidity after IFRS adoption } \\
\text { and The Liquidity before IFRS } \\
\text { adoption equals 0. }\end{array}$ & $\begin{array}{l}\text { Samples } \\
\text { Wilcoxon } \\
\text { Signed Rank } \\
\text { Test }\end{array}$ & \multirow{2}{*}{1.000} & $\begin{array}{l}\text { Retained the } \\
\text { Null } \\
\text { Hypothesis }\end{array}$ \\
\hline
\end{tabular}

Asymptotic significances are displayed. The significance level is .05.

The result of hypotheses test as shown on the above table revels that, there is nothing significantly difference in liquidation position of Indian SMSEs before IFRS and after IFRS adoption. This means, the liquidity position of SMSEs significantly decreased after using IFRS in accounting practice. This result support the IFRS adoption contingency theory, hence result of our first hypotheses may be considered if some area modified as to reflect the practice of local.

H02: The performance growth of Indian SMSEs is not significantly affected after IFRS adoption.

Table - 5: Effect of IFRS on Performance Growth of Indian SMSEs. Hypothesis Test Summary

\begin{tabular}{|l|l|l|l|l|}
\hline & \multicolumn{1}{|c|}{ Null Hypothesis } & \multicolumn{1}{|c|}{ Test } & \multicolumn{1}{c|}{ Sig. } & \multicolumn{1}{|c|}{ Decision } \\
\hline \multirow{4}{*}{1} & $\begin{array}{l}\text { Related- } \\
\text { The median of differences between } \\
\text { The PERG after IFRS adoption and } \\
\text { The PERG before IFRS adoption } \\
\text { equals 0. }\end{array}$ & $\begin{array}{l}\text { Samples } \\
\text { Wilcoxon } \\
\text { Signed Rank } \\
\text { Test }\end{array}$ & .144 & Retained the \\
Null \\
Hypothesis
\end{tabular}

Asymptotic significances are displayed. The significance level is .05.

Table 5 shows the result of effect of IFRS on performance growth of SMSEs. From the result, it reveals that IFRS does not affect significantly. From the result it confirms that adoption IFRS improves in reporting system of finance consistently thereby performance growth and risk associated to company is lower which resulted in constant growth. However, the result of P-value is 0.144 which is greater than the significant level i.e. 0.05 which support the contingency theory of adoption IFRS. 
$\mathrm{H}_{03}$ : The return on asset of Indian SMSEs is not significantly affected after IFRS adoption.

Table-6: Effect of IFRS on ROA of Indian's SMSEs Hypothesis Test Summary

\begin{tabular}{|c|c|c|c|c|}
\hline & Null Hypothesis & Test & Sig. & Decision \\
\hline 1 & $\begin{array}{l}\text { The median of differences between } \\
\text { The ROA after IFRS adoption and } \\
\text { The ROA before IFRS adoption } \\
\text { equals } 0 \text {. }\end{array}$ & $\begin{array}{l}\text { Related- } \\
\text { Samples } \\
\text { Wilcoxon } \\
\text { Signed Rank } \\
\text { Test }\end{array}$ & .043 & $\begin{array}{l}\text { Reject the } \\
\text { Null } \\
\text { Hypothesis }\end{array}$ \\
\hline
\end{tabular}

Asymptotic significances are displayed. The significance level is .05.

Table 6 shows the result of hypotheses test of third variable i.e. return on asset. This result gives sufficient reason not to accept the null hypothesis. Hence it approves that, adoption of IFRS significantly affecting ROS of Indian SMSEs. Since, the resulted P-Value of our test is 0.043 which is higher than the significant value of 0.05 , thus alternative hypothesis is accepted.

$\mathrm{H}_{04}$ : The Earnings per share of Indian SMSEs is not significantly affected after IFRS adoption.

Table - 7: Effect of IFRS on EPS of Indian SMSEs.

Hypothesis Test Summary

\begin{tabular}{|c|c|c|c|c|}
\hline & Null Hypothesis & Test & Sig. & Decision \\
\hline 1 & $\begin{array}{l}\text { The median of differences between } \\
\text { The EPS after IFRS adoption and } \\
\text { The EPS before IFRS adoption } \\
\text { equals } 0 \text {. }\end{array}$ & $\begin{array}{l}\text { Related- } \\
\text { Samples } \\
\text { Wilcoxon } \\
\text { Signed Rank } \\
\text { Test }\end{array}$ & .028 & $\begin{array}{l}\text { Reject the } \\
\text { Null } \\
\text { Hypothesis }\end{array}$ \\
\hline
\end{tabular}

Asymptotic significances are displayed. The significance level is .05.

In table -7 shows the result of hypotheses test of fourth variable i.e. EPS. The result reveals that IFRS adoption affect significantly on Indian SMSE's EPS. The test provides sufficient evidence for not to accept our null hypotheses. It means there is a positive effect on EPS of SMSEs after adoption of IFRS.

\section{Conclusion:}

On the basis of results found in this study, we can conclude that the IFRS adoption have influence significantly on the financial position and performance of Indian small and medium scale enterprises. Whereas the financial ratios like liquidity and profitability of SMSEs of India are not influenced significantly by adoption of IFRS. On other hand other two variables of this study such as EPS and ROA found a positively and significantly affected by the IFRS adoption.

\section{Bibliography:}

1. Adetula, D. E. (2016). Cost management and performance of manufacturing companies: A study of listed firms. innovation Management, Development Sustainability and Competitive Economic Growth, (pp. 4541-4546).

2. Alberti-Alhtaybat, L. H.-H. (2012). Mapping corporate disclosure theories. Journal of financial Reporting and accounting 10(1), 73-94.

3. Uzoma, A. O. (2016). Adoption of international financial reporting standards and its implication on bank performance in Nigeria: A comparative approach. Journal of internet banking and commerce 21(5), 1-20.

4. Aisbitt, S. (2006). Assessing the Effect of the Transition to IFRS on Equity: The Case of the FTSE 100. Accounting in Europe, Vol. 3, No. 1, pp. 117-133.

5. Agca, A. and Aktas, R. (2007). First Time Application of IFRS and Its Impact on Financial Ratios: A Study on Turkish Listed Firms. Problems and Perspectives in Management, Vol.5, No.2, pp.99-112

6. Armstrong, C. S., Barth, M. E., Jagolinzer, A. D. and Riedl, E. J. (2010), Market Reaction to the Adoption of IFRS in Europe. The Accounting Review, Vol. 85, No. 1, pp. 31-61.

7. Arouri, M., Levy, A. and Nguyen, D.K. (2010), ROE and Value Creation under IAS/IFRS: Evidence of Discordance from French Firms. European Financial and Accounting Journal, Vol.5, No.1, pp.84-112.

8. Aswal, A. K., Agarwal, G. and Das, S. (2011). Introduction of IFRS and Its Impact on Indian Corporate.

9. Aubert, F. and Grudnitski, G. (2011). The Impact and Importance of Mandatory Adoption of International Financial Reporting Standards in Europe. Journal of International Financial Management and Accounting, Vol. 22, No. 1, pp. 1-26.

10. Bowrin, A. R. (2007). International Accounting Standards and Financial Reporting Uniformity: The Case of Trinidad and Tobago. Advances in International Accounting, Vol. 20, pp. 27-53 
11. Bruggemann, U., Hitz, J. M. and Sellhorn, T. (2013). Intended and Unintended Consequences of Mandatory IFRS Adoption: A Review of Extant Evidence and Suggestions for Future Research. European Accounting Review, Vol. 22, No. 1, pp. 1-37.

12. Byard, D., Li, Y. and Lu, Y. (2011). The Effect of Mandatory IFRS Adoption on Financial Analysts' Information Environment. Journal of Accounting Research, Vol. 49, No. 1, pp. 69-96.

13. Blanchette, M., Racicot, F., \& Girard, J. (2011). The Effects of IFRS on Financial Ratios: Early Evidence in Canada. Certified General Accountants Association of Canada, pp.1-57.

14. Callao, S., Jarne, J.I., \& Lainez, J.A. (2007). Adoption of IFRS in Spain: Effect on the comparability and relevance of financial reporting. Journal of International Accounting, Auditing and Taxation, Vol.16, pp. $148-178$.

15. Callao, S. Ignacio J. J. (2010). Have IFRS Affected Earnings Management in the European Union? Zaragoza Accounting and Finance Department Managerial Auditing Journal, Vol.19 (3), pp. 440-461

16. Chan, W. M., Devi, S. S., Lee, D. S. and Ng K. T. (2010). Convergence to International Financial Reporting Standards (IFRS): The Need to Tighten the Rule on Divisible Profit. African Journal of Business Management, Vol. 4, No. 17, pp. 3588-3596.

17. Clarkson, P., Hanna, J. D., Richardson, G. D. and Thompson, R. (2011). The Impact of IFRS Adoption on the Value Relevance of Book Value and Earnings. Journal of Contemporary Accounting and Economics, Vol. 7, No. 1, pp. 1-17.

18. Cordazzo, M. (2008). The Impact of IAS/IFRS on Accounting Practices: Evidence from Italian Listed Companies. Seminaire DEMA/ERM

19. Daske, H., Hail, L., Leuz, C. and Verdi, R. (2008). Mandatory IFRS Reporting Around the World: Early Evidence on the Economic Consequences. Journal of Accounting Research, Vol. 46, No. 5, pp. $1085-1142$

20. Dimitrios, B., Nikolaos, E., Konstantinos, P., Dimitrios, V. (2013). The Impact of IFRS on Ratios of Listed and New Listed Companies of Athens Exchange. International Journal of Business and Social Research, Vol.3, No.5, pp. 139-157.

21. Djatej, A., Zhou, D., Gorton, D. and McGonigle, W. (2011). Critical Factors of IFRS Adoption in the US: An Empirical Study. Journal of Finance and Accountancy, Vol. 1, No. 14

22. Gupta, R. K. (2012). Impact on Economic Activities by Adoption of International Financial Reporting Standards by Indian Companies. Dissertation, Christ University.

23. Holm, C., Schøler, F., Lønne, H. and Maingot, M. (2008). A Study of the Adoption and Implementation of International Financial Reporting Standards in the Two EU Countries of Denmark and Ireland and New Zealand, a Non-EU Country. Accounting Research Group.

24. Hung, M. and Subramanyam, K.R. (2007). Financial Statement Effects of Adopting International Accounting Standards: The Case of Germany. Review of Accounting Studies, Vol.12(4), 623-657,

25. Iwata, E. (2010). Will Going Global Extend to Accounting? Switching to International Rules Has Its Pros and Cons. USA TODAY, January 6, p. B01

26. Jain, P. (2011). IFRS Implementation in India: Opportunities and Challenges. World Journal of Social Sciences, Vol. 1, No. 1, pp. 125136

27. Jaruga, A., Fijalkowska, J., Jaruga-Baranowska, M. and Frendzel, M. (2007). The Impact of IAS/IFRS on Polish Accounting Regulations.

28. Adebimpe, O. U. and Ekwere, R. E. (2015). IFRS adoption and value relevance of financial statement of Nigeria listed banks. International journal of finance and accounting, 4(1), 1-7.

29. Adetula D. T., (2016). Financial Accounting Numbers and the Emerging Nigerian Stock Market. The Social Sciences, 11, 3434-3439.

30. Adetula, D.T., Nwobu, O., Owolabi, F. (2014). Career advancement of female accountants in accounting professional practice in Nigeria. Vision 2020: Sustainable Growth, Economic Development, and Global Competitiveness - Proceedings of the 23rd International Business Information Management Association Conference, IBIMA 2014

31. Ahmed Zakari and Co - Chartered Accountants and Entop Consulting Ltd UK. (2011). International Financial Reporting Standards (IFRS): An Essential course for Getting to "KNOW IFRS". The Lagoon Restaurant, Ozumba Mbadiwe Street, Victoria Island Lagos.

32. Ailemen, I., and Akande, A. (2012). International financial reporting standards (IFRS): benefits, obstacles and intrigues for implementation in Nigeria. Research Journal of Finance and Accounting, $3(10), 143-151$.

33. Alberti-Alhtaybat, L., Hutaibat, K. and Al-Htaybat, K. (2012) Mapping corporate disclosure theories. Journal of Financial Reporting and Accounting, 10 (1): 73-94.

34. Asein, A.A. (2011). International financial reporting standards: imperatives of the new financial reporting framework. The Nigeria Accountant. 44(4), 16-25. 
35. Banji, O. O. (2010). SME: Issues, Challenges and Prospects. Presentation at FSS 2020 International Conference.

36. Core, J.E. (2001) A review of the empirical disclosure literature: discussion, Journal of Accounting and Economics, 31, 441-456.

37. Eluyela, D.F., Akintimehin, O.O., Okere, W., Ozordi, E., Osuma, G.O., Ilogho, S.O., Oladipo, O.A. (2018). Datasets for board meeting frequency and financial performance of Nigerian deposit money banks. Data in brief, 19, 1852-1855.

38. Eluyela, D.F., Akintimehin, O.O., Okere, W., Ozordi, E., Osuma, O.G., Ilogho, S.O., Oladipo, O.A. (2018). Board meeting frequency and firm performance: examining the nexus in Nigerian deposit money banks. Heliyon, 4,

39. Gbandi, E.C., and Amissah, G. (2014). Financing options for small and medium enterprises (SMEs) in Nigeria. European scientific journal, 10(1), 1-10.

40. Hung, M. and Subramanyam, K.R. (2004). Financial statement effects of adopting international accounting standards: the case of Germany. Review of accounting studies.

41. IASB (2016). Pocket guide to IFRS standards: the global reporting language. Retrieved from www.ifrs.org.

42. Ibiamke, N.A. and Ateboh-Briggs P.B. (2014). Financial ratios impact of international financial reporting standards (IFRS) in Nigeria. International Journal of Business and Management Invention. 3(3), 50-59.

43. Iyoha, F.O and Faboyede, S.O. (2011). Adopting International Financial Reporting Standards (IFRS) A Focus on Nigeria. International Journal of Research in Commerce and Management. 2(1), 35-40.

44. Li, S. (2010). Does Mandatory Adoption of International Financial Reporting Standards in the European Union reduce the Cost of Equity Capital? The Accounting Review, 85, 607-636.

45. Mary, J., Okoye, A., and Adediran O. (2013). Accounting standards in Nigeria. The journey so far. Research Journal of Business Management and Accounting, 2(1), 1-10.

46. Mohammed I. and Ali I. (2015). The effect of SMEs cost of capital on their financial performance in Nigeria." Journal of Finance and Accounting, 3(1), 8-11.

47. Nwaobia, A.N., Jayeoba, O.O., and Ajibade, A.T (2015). Financial statements analysis and IFRS adoption during the transitioning period: The case of Nigerian banks. Research Journal of accounting and finance, 6(20), 193-201.

48. Obazee, J.O. (2012). Issues and challenges of international financial reporting standards (IFRS) adoption for emerging economies. The Nigeria Accountant. 44(4), 26-28.

49. Ojeka S. and Mukoro D. (2010): International financial reporting standards (IFRS) and SMEs in Nigeria: Perceptions of academic. The International Journal of Research in Commerce and Management, 2(1), 13-19.

50. Okoye, P., and Akenbor, C. (2014). Financial reporting framework in Nigeria and the adoption of the IFRS. International Journal of Business and Economic Development, 2(1), 52- 63. 